\title{
Fistulization of hydatid mediastinal cyst to the anterior thoracic wall: case report
}

\author{
Serpil Sevinc, Ozgur Samanciar, Taner Ozturk, Saban Unsal, Seyda Ors Kaya \\ Department of Thoracic Surgery, Dr. Suat Seren Chest Disease and Thoracic Surgery Training \\ and Research Hospital, Izmir, Turkey
}

Kardiochirurgia i Torakochirurgia Polska 2014; 11 (4): 425-427

\begin{abstract}
Echinococcosis/hydatidosis is a frequent parasitic and zoonotic disease in the population engaged with agriculture and stockbreeding. It is seen most frequently in the liver and lung in adults. Mediastinal location of the disease is very rare. In this study we aimed to present a 31-year-old man having hydatid disease in the anterior mediastinum fistulated to the skin in the right subclavicular region, together with the literature. The patient was operated on through a partial sternotomy incision, and excision of the cyst and the fistula was performed. Key words: hydatid cyst, anterior mediastinal cyst, sternotomy.
\end{abstract}

\section{Introduction}

There are four different sub-types of hydatid disease. The most frequently seen are Echinococcus granulosus and E. multilocularis, leading to alveolar echinococcosis. Mediastinal disease is very rare [1]. Intrathoracic extrapulmonary disease is generally located in the mediastinum, pleura, pericardium and the thoracic wall [2]. The incidence of the disease in Turkey was reported as 6.3/100 000 [3], while the incidence of mediastinal hydatid cyst is $0.1-0.5 \%$. Most of them are located in the posterior mediastinal compartment (55\%), whilst $36 \%$ are located in the anterior mediastinum [4]. The presented case is the first reported case of fistulization to the skin from mediastinal disease in the literature.

\section{Case report}

The 31-year-old man presented with swelling in the right subclavicular region. There was nothing pathological that could be detected on the chest X-ray. In computed thorax tomography scan, a multiloculated cystic lesion was seen, $5 \mathrm{~cm} \times 3 \mathrm{~cm}$ in diameter, located in the anterior mediastinum, and a catheter was placed to observe the tract of the fistula (Fig. 1, 2). It was observed that a lucid fluid and

\section{Streszczenie}

Bąblowica/echinokokoza jest częstym odzwierzęcym schorzeniem pasożytniczym w populacjach zajmujących się uprawą roli i hodowlą zwierząt. Pasożyty obserwuje się najczęściej w wątrobie i płucach dorosłych pacjentów. Śródpiersiowe umiejscowienie choroby występuje bardzo rzadko. W pracy przedstawiono przypadek 31-letniego chorego z bąblowicą w przednim śródpiersiu, która wytworzyła przetokę do prawego obszaru podobojczykowego, oraz przegląd literatury tematu. Pacjenta operowano przez częściową sternotomię. Usunięto torbiel oraz przetokę.

Słowa kluczowe: torbiel bąblowca, torbiel śródpiersia przedniego, sternotomia.

white membrane particles were drained from the fistula. The result of histopathological examination of this material was reported as "hydatid cyst membrane". Other physical examinations and laboratory findings were normal. Surgical intervention through a partial sternotomy was planned for the patient. In the surgical exploration, multiple cysts which had diameters of $2 \mathrm{~mm}$ to $2 \mathrm{~cm}$ were detected and extracted. The pericystic layer was excised. The operative field and the fistula were irrigated with hypertonic saline. The fistula tract under the sternocleidomastoid muscle from the anterior mediastinum was identified and curetted (Fig. 3, 4). The patient was discharged on the fourth postoperative day without any complications. Three courses of albendazole tablets with a dose of $10 \mathrm{mg} / \mathrm{kg} /$ day were applied postoperatively. Each course lasted for three weeks, and the next course was started after a 10-day break after checking the blood tests for screening of liver functions.

\section{Discussion}

Echinococcosis/hydatidosis is the most frequent parasitic and zoonotic disease in the population engaged in agriculture and stockbreeding. It is endemic in the Mediterranean countries such as Turkey. Mediastinal location of 


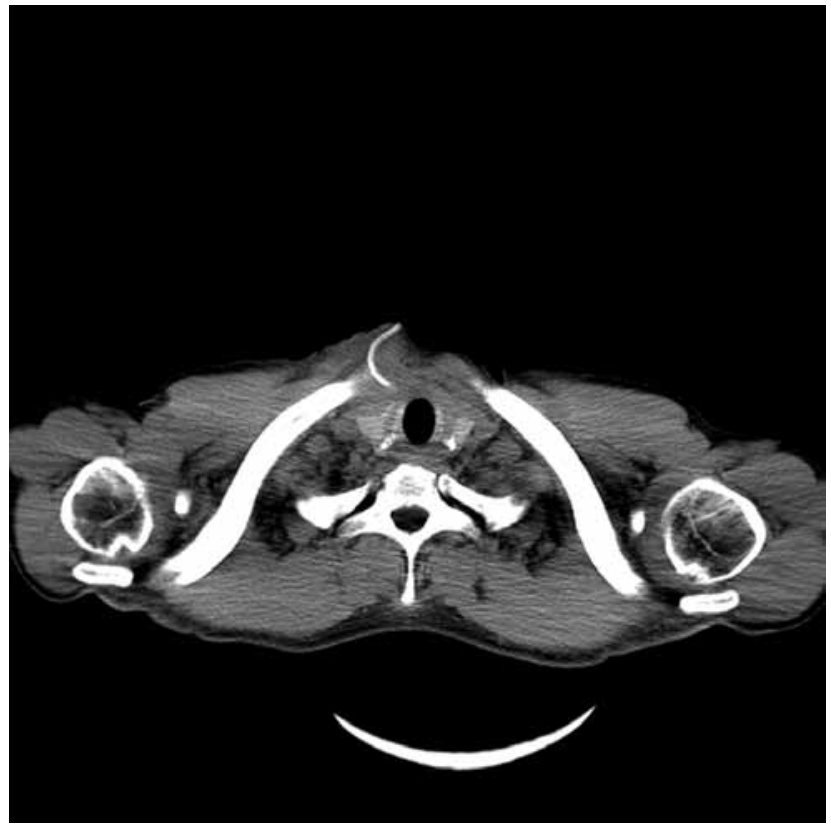

Fig. 1. A computed tomography scan of the patient: radio-opaque tube placed in the fistula tract can be seen

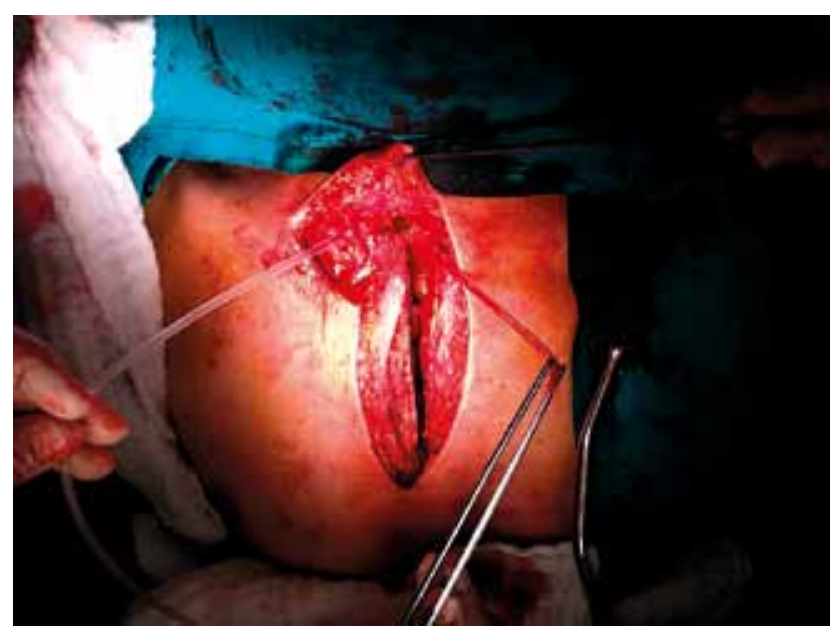

Fig. 3. Intraoperative image: partial sternotomy, and the fistula tract followed

hydatid cysts is extremely rare [1]. Ulku et al. mentioned a total 14 cases $(10.5 \%)$ in a series of 133 cases with intrathoracic extrapulmonary hydatid disease, and only three of them were at the anterior mediastinum [5].

Patients may be asymptomatic but symptoms can be present due to the pressure of the enlarged cyst on the surrounding organs [5]. Gursoy et al. reported that chest pain and dyspnea were present in $70 \%$ of cases of intrathoracic extrapulmonary hydatid cyst [6]. Since the mediastinal cystic lesion was ruptured and fistulization to the skin was present, swelling was the only symptom in our case. Bilio-bronchial fistula due to hydatid disease and aortobronchial fistula cases leading to massive hemoptysis was also reported in the literature $[7,8]$.

Ozyurtkan et al. reported two cases of anterior mediastinal cysts approached by thoracotomy [1]. We imple-

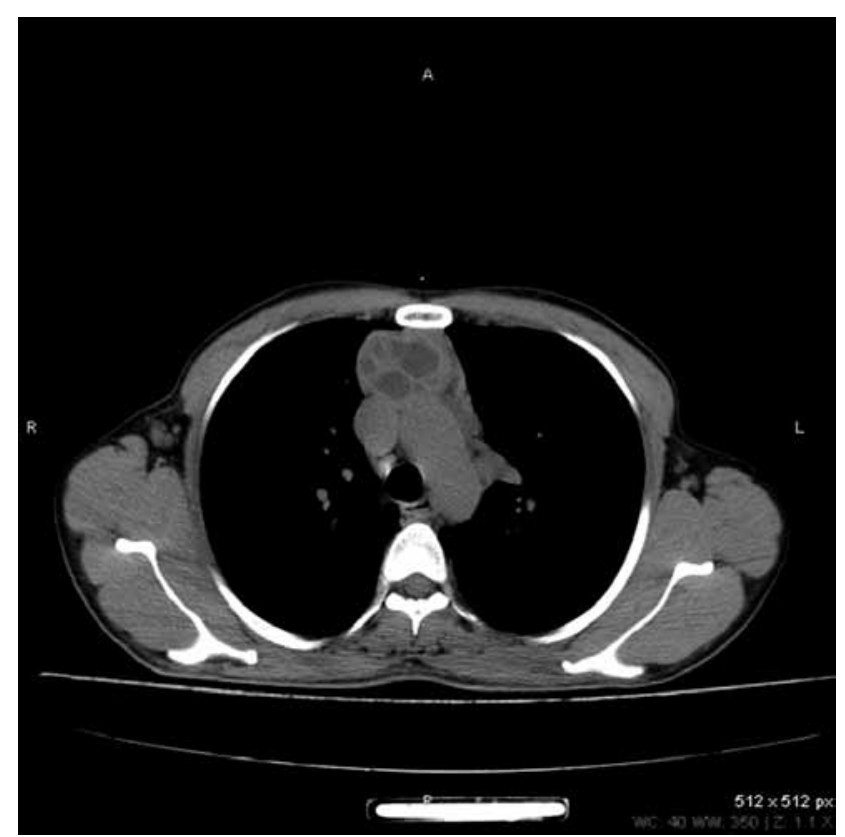

Fig. 2. A computed tomography scan of the patient: cystic lesion in the anterior mediastinal area

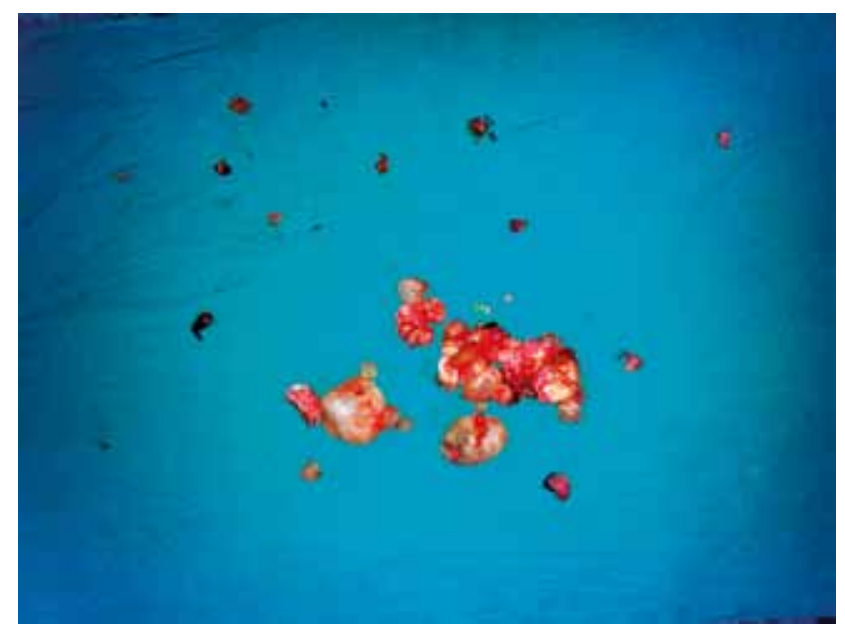

Fig. 4. Intraoperative image: cyst hydatid membrane and daughter vesicles

mented fistula tract repair, multiple cystectomy via partial sternotomy and local curettage, which were successfully performed in our case. Eroglu et al. also reported four patients who had hydatid cysts in the anterior mediastinum. They approached three cases by sternotomy and one case by thoracotomy [9].

In conclusion, hydatid disease should be included in the differential diagnosis in patients with an anterior mediastinal cystic mass in places where the disease is endemic. Surgical treatment should be applied immediately for cysts located too close to the vital mediastinal organs to avoid perforation and contamination of the mediastinum.

\section{Disclosure}

Authors report no conflict of interest. 


\section{References}

1. Özyurtkan MO, Koçyiğit S, Çakmak M, Ozsoy IE, Balci AE. Case report: mediastinal hydatid cysts. Türkiye Parazitol Derg 2009; 33: 179-181.

2. Oğuzkaya F, Akçalı Y, Kahraman Ç, Bilgin $M$, Şahin A. Unusually located hydatid cysts: intrathoracic but extrapulmonary. Ann Thorac Surg 1997; 64: 334-337.

3. Yazar S, Taylan Özkan A, Hökelek M, Polat E, Yılmaz H, Özbilge H, Üstün S, Koltas 9S, Ertek M, Sakru N, Alver O, Çetinkaya Z, Koç Z, Demirci M, Aktas H, Parsak CK, Özerdem D, Sakman G, Cengiz ZT, Özer A, Keklik K, Yemenici N, Turan M, Dastan A, Kaya E, Sönmez Tamer G, Girginkardesler N, Türk M, Sınırtas M, Evci C, Kılıçturgay S, Mutlu F, Artıs T. Türkiye'de 2001-2005 yılları arasında kistik ekinokokkozis. Türkiye Parazitol Derg 2008; 32: 208-220.

4. Thameur H, Chenik S, Abdelmoulah S, Bey M, Hachicha S, Chemingui M, Mestiri T, Chaouch H. Thoracic hydatidosis: a review of 1619 cases. Rev Pneumol Clin 2000; 56: 7-15.
5. Ulkü R, Eren N, Cakir O, Balci A, Onat S. Extrapulmonary intrathoracic hydatid cysts. Can J Surg 2004; 47: 95-98.

6. Gursoy S, Ucvet A, Tozum H, Erbaycu AE, Kul C, Basok Ol. Primary intrathoracic extrapulmonary hydatid cysts: analysis of 14 patients with a rare clinical entity. Tex Heart Inst J 2009; 36: 230-233.

7. Buchholz S, Sowden D, Stapleton T, Pohlner P, Wright C. Massive haemoptysis due to aortobronchial fistula caused by pulmonary hydatidosis. Med J Aust 2009; 190: 222.

8. Kabiri EH, Traibi A, Arsalane A. Bilio-bronchial fistula due to hydatic disease: case report and review of the literature. Rev Pneumol Clin 2011; 67: 380-383.

9. Eroğlu A, Kurkcuoğlu C, Karaoglanoglu N, Tekinbas C, Kaynar H, Onbas O. Primary hydatid cysts of the mediastinum. Eur J Cardiothorac Surg 2003; 23: $257-258$ 